\title{
Dental anomalies in Dromiciops gliroides (Microbiotheria, Microbiotheriidae), Caenolestes fuliginosus and Rhyncholestes raphanurus (Paucituberculata, Caenolestidae)
}

\author{
Anomalías en la dentición de Dromiciops gliroides (Microbiotheria, Microbiotheriidae), \\ Caenolestes fuliginosus and Rhyncholestes raphanurus (Paucituberculata, Caenolestidae)
}

\author{
GABRIEL M. MARTIN
}

Laboratorio de Investigaciones en Evolución y Biodiversidad, Facultad de Ciencias Naturales, Sede Esquel, Universidad Nacional de la Patagonia, Sarmiento 849, CP 9200, Esquel, Chubut, Argentina;

e-mail: gmartin_ar@yahoo.com

\begin{abstract}
Dental anomalies are described after analyzing series of skulls and mandibles of three species of South American marsupials: the monito del monte (Dromiciops gliroides), the silky shrew-opossum (Caenolestes fuliginosus) and the Chilean shrew-opossum (Rhyncholestes raphanurus). The anomalies are classified into three categories: (1) supernumerary or missing teeth in normal positions of the dental series, (2) morphological anomalies like teeth fusion or anomalous crown shape, and (3) presence of teeth in unusual positions. Cusp fusion and supernumerary teeth at the end of the toothrow have been observed predominantly in $D$. gliroides. A tendency to find supernumerary or missing teeth is observed between the procumbent incisors and the second lower premolars in caenolestids. Possible causes for these anomalies and their morphofunctional value are discussed. A comparison with other marsupials is presented and discussed. Isolation of local populations and its effects on genetic drift processes might explain the high percentage of dental anomalies.
\end{abstract}

Key words: dental anomalies, Dromiciops, Caenolestes, Rhyncholestes.

\section{RESUMEN}

A partir del análisis de series de cráneos y mandíbulas del monito de monte (Dromiciops gliroides), el ratón marsupial sedoso (Caenolestes fuliginosus) y la comadrejita trompuda (Rhyncholestes raphanurus), se describen las anomalías en la dentición (incisivos, premolares, molares), clasificándose de acuerdo a tres categorías: (1) dientes supernumerarios o faltantes en alguna posición, (2) anomalías morfológicas tales como fusión de dientes o variaciones en el número de raíces, y (3) presencia de dientes en posiciones inusuales. Se observa una tendencia al desarrollo de dientes supernumerarios en cenoléstidos, o pérdida de elementos dentarios en la mandíbula, principalmente entre los incisivos procumbentes y el segundo premolar. En $D$. gliroides, la tendencia es hacia la fusión de cúspides y la producción de dientes supernumerarios al final de la hilera molar superior (apareciendo como $\mathrm{M}^{5}$ ). Se discuten las posibles causas de estas anomalías y su valor morfofuncional. Se presentan y discuten las frecuencias de anomalías encontradas con otros marsupiales. Se propone que fenómenos de aislamiento y sus efectos sobre procesos de deriva génica estarían explicando los altos porcentajes de anomalías aquí presentados.

Palabras clave: anomalías en la dentición, Dromiciops, Caenolestes, Rhyncholestes.

\section{INTRODUCTION}

Dental anomalies in mammals are relatively infrequent due to the fact that any deformation in tooth shape and cusp arrangement, and missing or supernumerary teeth in the occluding sections of the toothrow, would result in malocclusion and eventually an unviable individual. Apart from the work by Archer (1975), no attempts have been made to typify and categorize dental anomalies in marsupials, especially with reference to Neotropical species. Only the works of Bensley (1903, 1906), Osgood (1921, 1924), and González (2000) 
referred to dental anomalies in South American species. Both Bensley and González mentioned supernumerary teeth in the genus Didelphis (D. marsupialis and D. albiventris, respectively). Bensley (1903) documented a caenolestid with five incisor-type teeth in both mandibles, while Osgood $(1921,1924)$ presented information on a single specimen of Caenolestes obscurus (=fuliginosus) with different lower teeth numbers in each mandible (five left? opposite four right?) and a single specimen of Orolestes (= Lestoros) inca, showing a three-rooted tooth which he describes as fused lower canine and first premolar. No information is available for other South American marsupials with more restricted distributions (e.g., Dromiciops gliroides and other caenolestids) or the highly speciose and abundantly sampled didelphids.

The monito del monte (Dromiciops gliroides Thomas, 1894) inhabits the temperate rainforests of southern Chile and Argentina and is the only living species of the Order Microbiotheria (Reig 1955, Nowak 1999). Although living in South America, the species is considered more closely related to the Australian marsupial radiation (Szalay 1982, Westerman et al. 1991, Springer et al. 1998, Nilsson et al. 2004) or a sister group to all other marsupial lineages, living and extinct (Hershkovitz 1999, and references therein). Different aspects of this enigmatic species have been covered by several authors, e.g., Szalay $(1982,1994)$ on tarsal bone anatomy, Kirsch et al. $(1991,1997)$ on DNA hybridization; Giannini et al. (2004) on postweaning ontogeny, but there are no studies on tooth development.

The common shrew-opossum (Caenolestes fuliginosus Tomes, 1863) and the Chilean shrew-opossum (Rhyncholestes raphanurus Osgood, 1921) are two of the six extant species of the Order Paucituberculata (Albuja \& Patterson 1996, Brown 2004), a peculiar group of South American marsupials with pseudodiprotodont dentition and a distribution restricted to the humid and cold ecosystems of the Andean cordillera. Scarce information is available about these species due to a highly localized distribution and difficult trapping in their rather inaccessible typical environments. Caenolestes fuliginosus is the type species of the genus Caenolestes, and is distributed along the Andes from northwestern Venezuela through Colombia, Ecuador and northernmost Perú (Brown 2004). It inhabits cloud forests and "páramos" at high elevations, from 2,200 to 4,300 m. (Albuja \& Patterson 1996). Rhyncholestes raphanurus is the southernmost representative of the Order Paucituberculata, living in very humid patches in temperate rainforests of Chile and adjacent Argentina (Patterson \& Gallardo 1987, Patterson et al. 1989, Birney et al. 1996), and is one of the South American marsupials with the most isolated and restricted distribution.

In this context the data herein presented adds valuable information on the dental morphology of three species of Neotropical marsupials. The main objectives of this work are twofold. Firstly, I describe the dental anomalies found in each species and categorize them. Secondly, I discuss the importance of these anomalies in light of the distribution and evolutionary history of each species. A comparison with other marsupials is presented and the significance of the anomalies from a functional point of view is discussed.

\section{MATERIAL AND METHODS}

Specimens of the caenolestids Caenolestes fuliginosus and Rhyncholestes raphanurus and the microbiotheriid Dromiciops gliroides were examined (Appendix 1).

Dental anomalies were classified into three main categories (modified from Archer 1975): (1) supernumerary or missing teeth in any position, loss not obviously produced by a physical disturbance or accident of the sample, (2) morphological anomalies (e.g., fusion of teeth, variation in crown shape), and (3) presence of teeth in unusual positions. These categories are not exclusive, meaning that a supernumerary tooth could have anomalous crown morphology and be present in an unusual position (e.g., BMNH 1954.297). Supernumerary teeth were defined according to their resemblances to existing teeth, but their crown shape was not considered in the category of morphological anomalies.

Dental homologies follow Luckett \& Hong (2000) for caenolestids and Luckett (1993) for D. gliroides. Upper and lower dentitions are designated by a numerical superscript and subscript, respectively. Therefore, the teeth found in adult dentitions of caenolestids are designated as follows: upper and lower 
incisors, $\mathrm{I}^{1-4}$ and $\mathrm{I}_{1-3}$ (from mesial to distal); canines, $\mathrm{C}^{1}$ and $\mathrm{C}_{1}$; premolars, $\mathrm{dP}^{1-2}$ and $\mathrm{dP}_{1-2}$, and $\mathrm{P}^{3}$ and $\mathrm{P}_{3}$; molars, $\mathrm{M}^{1-4}$ and $\mathrm{M}_{1-4}$. In $D$. gliroides the dental homologies are: $\mathrm{I}^{1-5}$ and $\mathrm{I}_{1-4}$ for upper and lower incisors; canines, $\mathrm{C}^{1}$ and $\mathrm{C}_{1}$; premolars, $\mathrm{dP}^{1-2}$ and $\mathrm{dP}_{1-2} ; \mathrm{P}^{3}$ and $\mathrm{P}_{3}$; molars, $\mathrm{M}^{1-4}$ and $\mathrm{M}_{1-4}$. The single functional deciduous tooth in each jaw quadrant, when referenced, is designated $\mathrm{dP}^{3}$ or $\mathrm{dP}_{3}$ for the three species analyzed. When both upper and lower teeth are referred to neither subscript nor superscript is used (e.g., dP1). Terminology of cusp patterns follows Goin (2003), "n" represents number of specimens analyzed.

Comparisons with other marsupials were made when properly documented in the literature (i.e., specimen number and type of anomaly) and the numbers of sample localities for specimens with anomalous and normal dentitions were taken into account.

\section{RESULTS}

The percentage of anomalies in the three species varied from $29.6 \%$ (i.e., Rhyncholestes raphanurus) to $8.8 \%$ (i.e., Dromiciops gliroides) (Table 1). The smallest number of specimens with anomalies in comparison to normal specimens is found in D. gliroides (8 of 91, respectively). C. fuliginosus and $R$. raphanurus showed a higher number of specimens with anomalies ( 5 of 40 and 8 of 19, respectively). The list of anomalies and their frequency according to sex in each species is presented in Table 1. Comparisons with other South American and some selected Australian marsupials are shown in Table 2.

The number of anomalies in D. gliroides is close to the highest observed for Australian marsupials (i.e., Antechinus flavipes) but the number of specimens analyzed is more than twice as large. D. gliroides presented anomalies in the first two categories (supernumerary or missing teeth and morphological anomalies), representing $8.8 \%$ of the total specimens analyzed $(\mathrm{n}=91)$. Morphological anomalies involving the shape of the crown and/or root number represented $5.4 \%$ (five specimens). Of these, two specimens had peg-like $\mathrm{dP}^{1}$ (IEEUACH 671 and IEEUACH 681), two had semi fused crowns with two cusps and three roots (IEEUACH 683 with $\mathrm{dP}_{1-2}$ fused; IEEUACH 687 with $\mathrm{dP}^{1-2}$ fused [Fig. 1]), and one specimen presented an anomalous three rooted $\mathrm{P}^{3}$ (IEEUACH 687), which had a widened talonid (resembling $\mathrm{M}^{1}$ ) and a wide and very well developed anterior cingulum.

\section{TABLE 1}

Dental anomalies and their percentage in three species of South American marsupials (Order

Microbiotheria and Paucituberculata). Percentages are given in relation to the total number of dental anomalies per species. Sex and number of anomalies per species are in parenthesis; $n$ is the total number of specimens analyzed

Anomalías dentarias y su porcentaje respectivo en tres especies de marsupiales sudamericanos (Orden Microbiotheria y Paucituberculata). Los porcentajes se dan en relación al número total de anomalías dentarias por especie. Sexo y número de anomalías por especie entre paréntesis; $n$ es el número total de especímenes analizados

\begin{tabular}{|c|c|c|c|}
\hline Type of anomaly & $\begin{array}{c}\text { Dromiciops gliroides } \\
\mathrm{n}=91\left(490^{\circ}, 37 \% \& \& 5\right. \\
\text { indetermined }\end{array}$ & $\begin{array}{l}\text { Caenolestes fuliginosus } \\
\mathrm{n}=40\left(22 \sigma^{\prime} \& 18 \%\right)\end{array}$ & $\begin{array}{c}\text { Rhyncholestes raphanurus } \\
\mathrm{n}=27\left(17 \sigma^{\prime}, 8 \% \& 2\right. \\
\text { indetermined })\end{array}$ \\
\hline Supernumerary teeth & $2\left(2 \sigma^{\pi}\right), 2.2 \%$ & $2\left(10^{x} 1 \%\right), 5 \%$ & $2\left(2 \sigma^{x}\right), 7.4 \%$ \\
\hline Missing teeth & $1\left(10^{7}\right), 1.1 \%$ & $2\left(10^{x} 19\right), 5 \%$ & 4 (30'1\%), $14.8 \%$ \\
\hline Fused teeth & $2\left(10^{x} 19\right), 2.2 \%$ & 0 & 0 \\
\hline Anomalous shape & $3\left(30^{7}\right), 3.3 \%$ & $1\left(10^{7}\right), 2.6 \%$ & $2(2 q), 7.4 \%$ \\
\hline Teeth in unusual positions & 0 & $1\left(10^{\pi}\right), 2.6 \%$ & 0 \\
\hline $\begin{array}{l}\text { Total number and percentage of } \\
\text { specimens with anomalies }\end{array}$ & 8 (70 1 1 $), 8.8 \%$ & $6\left(4 \sigma^{2} 2 \%\right), 15 \%$ a & 8 (50 3 3 \%), $29.6 \%$ \\
\hline
\end{tabular}

\footnotetext{
a includes specimen BMNH 1954.297 with supernumerary tooth in an unusual position counting in two categories

a incluye al espécimen BMNH 1954.297 que presenta un diente supernumerario en una posición inusual contado en dos categorías
} 
The other anomalies found were missing or supernumerary teeth. Specimen IEEUACH 2164 with missing $\mathrm{dP}^{2}$, had $\mathrm{C}^{1}$ and $\mathrm{dP}^{1}$ displaced backwards towards $\mathrm{P}^{3}$, and a diastema between $\mathrm{C}^{1}, \mathrm{dP}^{1}$ and $\mathrm{P}^{3}$. An extra peglike tooth at the end of the upper toothrow (M? ${ }^{5}$ ?) was found in two specimens (IEEUACH 673 and IEEUACH 674). In comparison, males ( $\mathrm{n}=6 ; 12.2$ or $14.3 \%$ if the specimen with anomalies is taken separately) had more anomalies than females $(\mathrm{n}=1 ; 2.7 \%)$ and in higher proportions in relation to the number of males $(n=49)$ and females $(n=37)$ analyzed. The number of specimens analyzed and the percentage of anomalies found in Caenolestes fuliginosus (Table 2) is similar to that of Antechinus flavipes, which is higher than the rest of the Australian marsupials presented by Archer (1975). Caenolestes fuliginosus presented anomalies in all categories, representing $12.5 \%$ of the total specimens studied $(n=40)(15 \%$ if anomalies are taken individually, but see discussion). Supernumerary teeth were present in two specimens (BMNH 1954.287 [Fig. 2A] and $\mathrm{BMNH}$ 1954.297) and absent teeth were observed in two additional specimens $(\mathrm{BMNH}$ 1954.286 [Fig. 2B] and BMNH 1934.9.10.2.17). A single rooted supernumerary tooth was found in the anterior palate (premaxillary bone) of BMNH 1954.297, lingual to $\mathrm{I}^{2-3}$ (Fig. 3). Its shape does not allow for a proper classification as incisor, canine or premolar. The other supernumerary tooth (in BMNH 1954.287) and both cases of absent teeth (BMNH 1954.286 and BMNH 1934.9.10.2.17) occur between the procumbent incisors and the first identifiable premolar $\left(\mathrm{dP}_{2}\right)$. Only one specimen (BMNH 1954.295) exhibited morphological anomalies, consisting of a transversely oriented single rooted left $\mathrm{dP}^{2}$. Males had almost the same number of anomalies than females (three to two) when compared, but in proportion there were more males (13.6 or $18.2 \%$ if specimen with anomalies is taken separately) with anomalies than females $(11.1 \%)$. The high percentage of anomalies found in Rhyncholestes raphanurus (Table 2), despite the small sample size $(\mathrm{n}=$ 27), is the highest of all specimens analyzed and any other marsupial presented here or found in the literature. Rhyncholestes

TABLE 2

Proportions of dental anomalies in South American and Australian marsupials (orders Microbiotheria, Paucituberculata, Didelphimorphia, Dasyuromorphia and Peramelemorphia)

Proporciones de anomalías dentarias en marsupiales sudamericanos y australianos (órdenes Microbiotheria, Paucituberculata, Didelphimorphia, Dasyuromorphia y Peramelemorphia)

\begin{tabular}{|c|c|c|c|}
\hline Species & Without anomalies & With anomalies & Total number of specimens \\
\hline Dromiciops gliroides & $83(91.2 \%)$ & $8(8.8 \%)$ & 91 \\
\hline Caenolestes fuliginosus & $35(85 \%)$ & $5(15 \%)$ & 40 \\
\hline Rhyncholestes raphanurus & $19(70.4 \%)$ & $8(29.6 \%)$ & 27 \\
\hline Thylamys venustus ${ }^{\mathrm{a}}$ & $253(100 \%)$ & 0 & 253 \\
\hline Thylamys pallidior & $110(100 \%)$ & 0 & 110 \\
\hline Lestodelphys hallib & $300(100 \%)$ & 0 & 300 \\
\hline Didelphis albiventris ${ }^{\mathrm{c}}$ & $113(99.1 \%)$ & $1(0.9 \%)$ & 114 \\
\hline Didelphis marsupialis ${ }^{\mathrm{d}}$ & $78(98.7 \%)$ & $1(1.3 \%)$ & 79 \\
\hline Sminthopsis murina & $133(95 \%)$ & $7(5 \%)$ & 140 \\
\hline Anthechinus flavipes ${ }^{\mathrm{e}}$ & $36(87.8 \%)$ & $5(12.2 \%)$ & 41 \\
\hline Dasyurus geoffroii ${ }^{\mathrm{e}}$ & $43(95.6 \%)$ & $2(4.4 \%)$ & 45 \\
\hline Planigale maculata & $41(95.3 \%)$ & $2(4.7 \%)$ & 43 \\
\hline
\end{tabular}

a includes specimens of Thylamys venustus, T. cinderella and T. sponsorius; ${ }^{\mathrm{b}}$ specimens from Martin (2003, 2005); ${ }^{\mathrm{c}}$ from González (2000); d from Bensley (1906); efrom Archer (1975)

a incluye especímenes de Thylamys venustus, T. cinderella y T. sponsorius; bespecímenes tomados de Martin (2003, 2005);

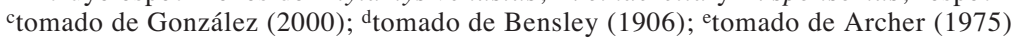




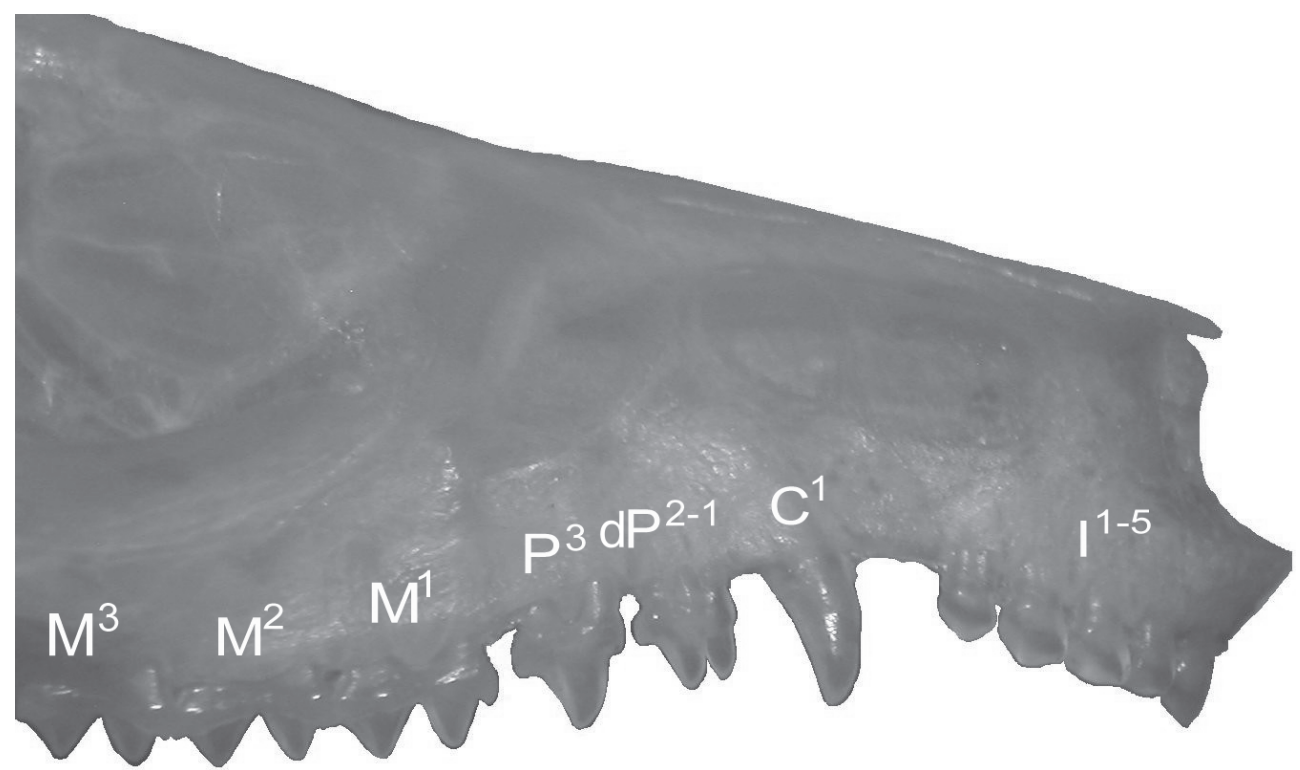

Fig. 1: Fused $\mathrm{dP}^{1-2}$ in Dromiciops gliroides (IEEUACH 687). $\mathrm{dP}^{1-2}$ fusionados en Dromiciops gliroides (IEEUACH 687).

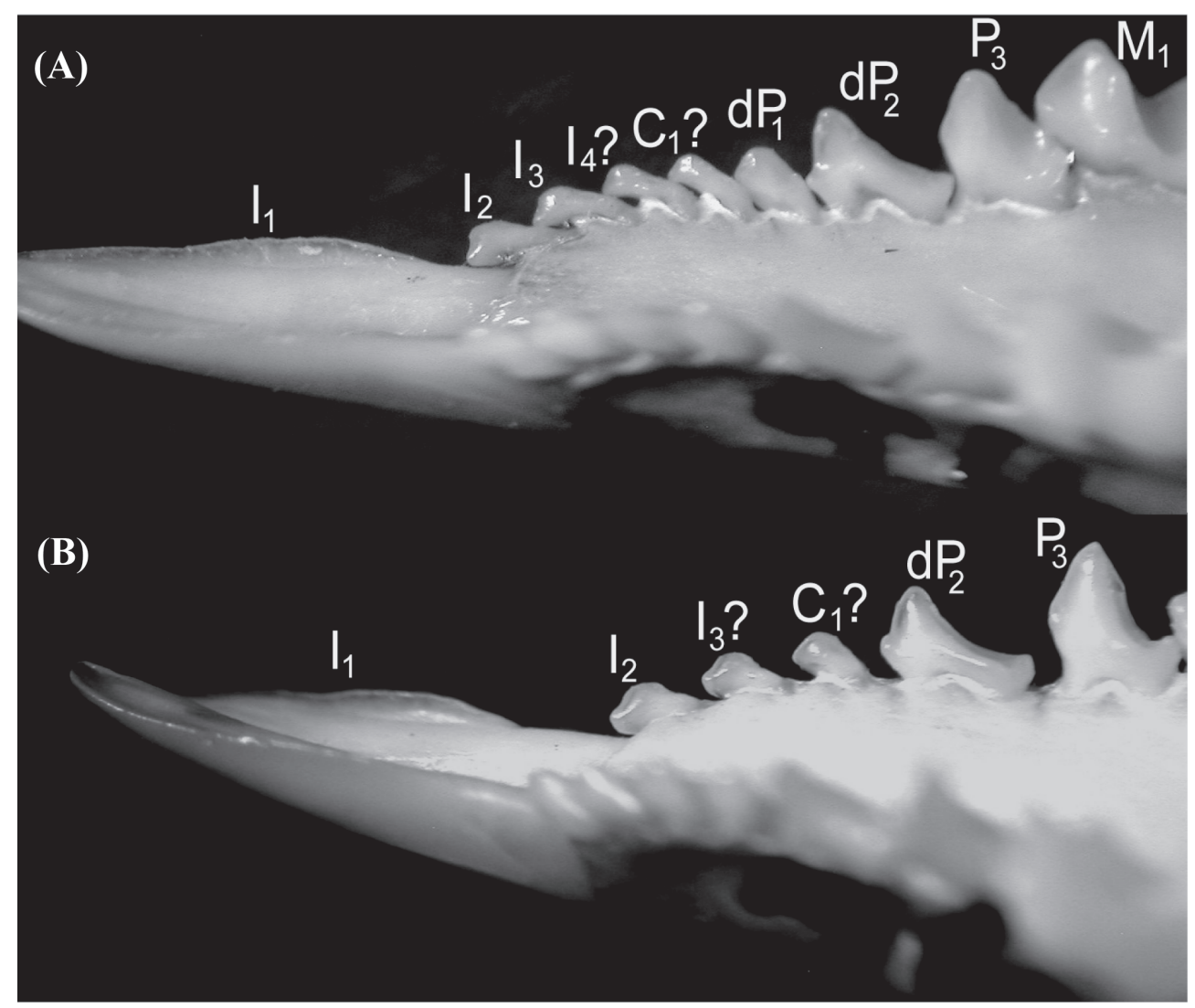

Fig. 2: Supernumerary (A) and missing (B) teeth in Caenolestes fuliginosus (BMNH 1954.287 and BMNH 1954.286, respectively).

Dientes supernumerarios (A) y faltantes (B) en Caenolestes fuliginosus (BMNH 1954.287 y BMNH 1954.286, respectivamente). 


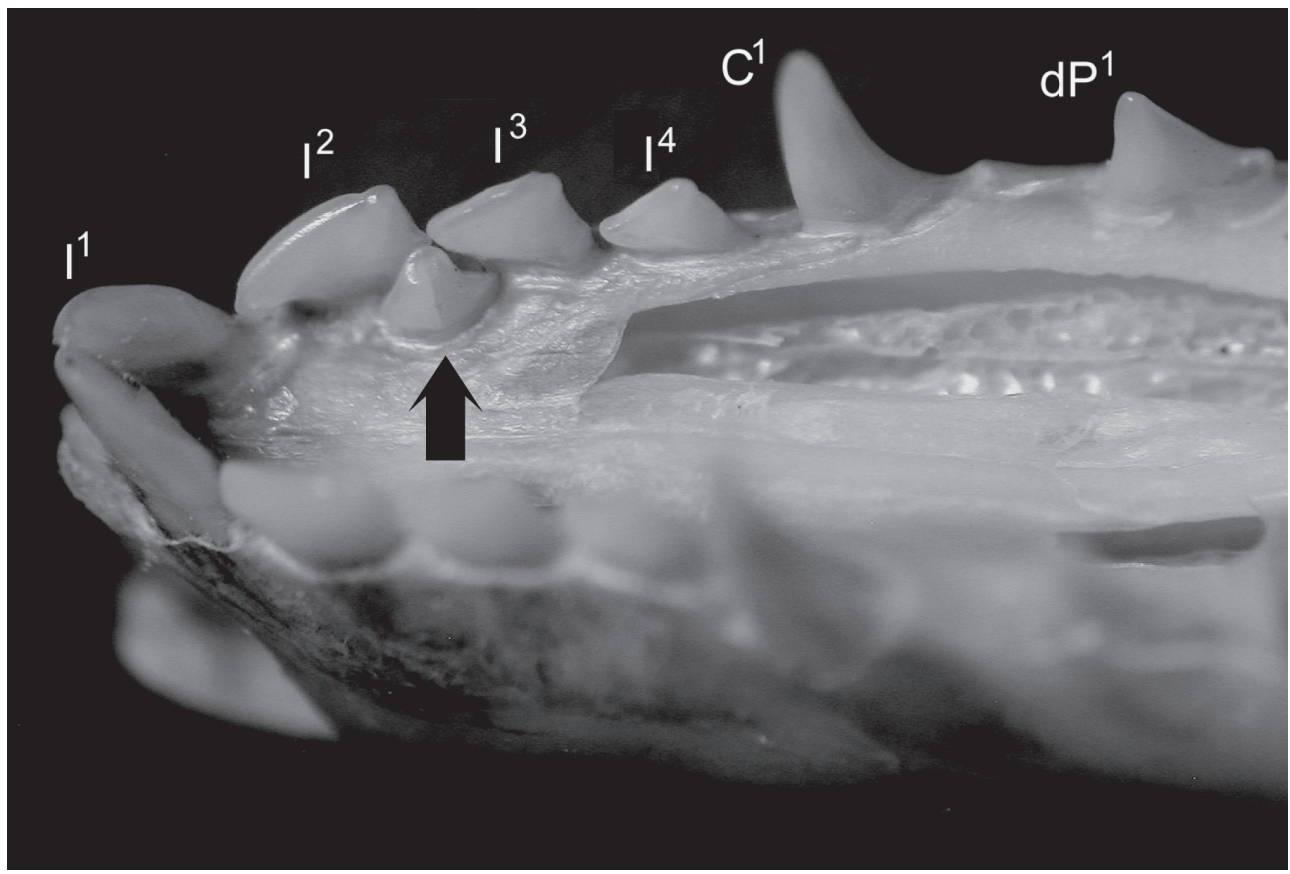

Fig. 3: Supernumerary tooth (black arrow) lingual to $\mathrm{I}^{2-3}$ in Caenolestes fuliginosus (BMNH 1954.297).

Diente supernumerario (flecha negra) lingual a $I^{2-3}$ en Caenolestes fuliginosus (BMNH 1954.297).

raphanurus showed anomalies in the first two categories, representing $22.2 \%$ of the specimens $(n=27)$ (Table 1$)$. Supernumerary teeth were present in two specimens (IEEUACH 948 [Fig. 4] and IEEUACH 2244) and missing teeth were found in four additional specimens. The supernumerary teeth could represent either $\mathrm{I}_{\mathrm{x}}, \mathrm{C}_{1}$ or $\mathrm{dP}_{1}$ (see discussion below). The absence of teeth was all found in different specimens and in different tooth positions, attributed to the following missing teeth: ${ }^{4}$ (IEEUACH 2250), $\mathrm{C}^{1}$ (IEEUACH 2245), $\mathrm{M}^{4}$ (IEEUACH 3998), $\mathrm{P}_{3}$ (IEEUACH 4000). The morphological anomalies found in this species comprise the presence of peg-like single rooted $\mathrm{M}^{4}$ in two specimens (IEEUACH 949 and IEEUACH 4522). In contrast, males ( $=5$ ) had more anomalies than females $(n=3)$, but because more males than females were in the sample the proportion of females with anomalies was higher than males (37.5 opposite $29.6 \%)$.

When compared to other marsupials, a high proportion of dental anomalies in $D$. gliroides (8.8\% from 15 localities), C. fuliginosus (13.6 $\%$ from four localities) and $R$. raphanurus $(29.3$
$\%$ from seven localities) were found (Table 2), with no direct relation to the number of sample localities. In comparison to small didelphids, the difference is remarkable: no dental anomalies were found in large samples of Thylamys pallidor $(\mathrm{n}=110$, from 22 localities), Thylamys venustus (including $T$. cinderella and $T$. sponsorius) $(\mathrm{n}=253$, from 25 localities $)$ and Lestodelphys halli $(\mathrm{n}>300$, from 10 localities) (Table 2).

\section{DISCUSSION}

The percentage of anomalies found in the three species of marsupials presented is surprisingly high in comparison to other mammals (Bensley 1903, 1906, Hall 1928, Hooper 1946, Dolgov \& Rossolimo 1964, Archer 1975, González 2000, Azorit et al. 2002). In several studies of eutherian dental series, including insectivores, carnivores, and ungulates, percentages of anomalies only reach values of $0.01 \%$ in Sorex (Hooper 1946), < $1 \%$ in Ursus (Hall 1928), 1.85 $\%$ in Canis lupus (Dolgov \& Rossolimo 1964) and $75 \%$ in Cervus elaphus hispanicus (Azorit 
et al. 2002), for example. In Australian marsupials (mostly dasyurids), Archer (1975) presented several cases of dental anomalies with different percentages of occurrence ranging from $1.4 \%$ in Sminthopsis murina to $12.2 \%$ in Antechinus flavipes. He also mentioned that Ziegler (1971) found supernumerary $\mathrm{I}^{5}$ in $22 \%$ of the skulls of Echymipera (although Archer couldn't find any of them in six skulls of Echymipera rufescens). Archer (1975) listed around 44 anomalies in the genus Macropus, mostly corresponding to Macropus giganteus, but provided no information on the number of specimens examined. Unfortunately, he did not present a comprehensive table including species analyzed and type of anomaly, thus making comparisons with the present work a little troublesome. Table 2 includes some of his information, along with unpublished data on Thylamys pallidior, T. venustus (including $T$. cinderella and T. sponsorius), Lestodelphys halli and that from Bensley (1906) and González (2000), because a comparison could be made between total numbers of specimens examined and specimens with or without anomalies. A very small percentage of anomalies were found in didelphid marsupials (with a maximum of < $1.3 \%$ in Didelphis marsupialis), despite the many specimens analyzed (Table 2). The case of Lestodelphys halli is interesting because no anomaly was found in more than 300 specimens, coming from several localities throughout its range but mainly concentrated in west central Patagonia (see Martin 2003, 2005, for a list of localities and specimens). On the other hand the type specimen of Cryptonanus chacoensis (Voss et al. 2005) (BMNH 1904.1.5.48) shows an anomalous right $\mathrm{dP}^{1}$ with three roots and a molariform crown (personal observation). The three species studied here have anomalies within particular characteristics. In D. gliroides the anomalies were found predominantly in premolars and molars, without any deviation from the normal condition in the incisor and canine tooth positions. In $C$. fuliginosus and $R$. raphanurus the tendency is to present supernumerary or missing teeth between the procumbent $\mathrm{I}_{1}$ and $\mathrm{dP}_{2}$.

In $D$. gliroides morphological anomalies were predominant at the premolar region; supernumary teeth were present posterior to $\mathrm{M}^{4}$. The fusion of teeth in both upper and lower quadrants occurred between the first two premolars and apparently includes the dentine and pulp chambers, forming a two crowned/ three rooted tooth, probably involving epithelial and mesenchymal germ layers. Reasons for tooth fusion are still not clear, but might include physical forces producing close contact between developing teeth and certain genetic predisposition (Nunes et al. 2002). Although the number of specimens with these anomalies is low (only two), this observation agrees with the developmental pattern of didelphids, caenolestids, and dasyurids (Luckett 1993, Luckett \& Woolley 1996, Vidigal \& Patton 1996, Luckett \& Hong 2000, Martin 2005, Van Nievelt \& Smith 2005), where both $\mathrm{dP} 1$ and $\mathrm{dP} 2$ erupt almost simultaneously but later than $\mathrm{dP} 3$, as described for Monodelphis domestica (Van Nievelt \& Smith 2005). The later replacement and eruption of the third premolar (the only one replaced in the marsupial dentition) makes it improbable for this tooth to fuse more than superficially with the second premolar (dP2).

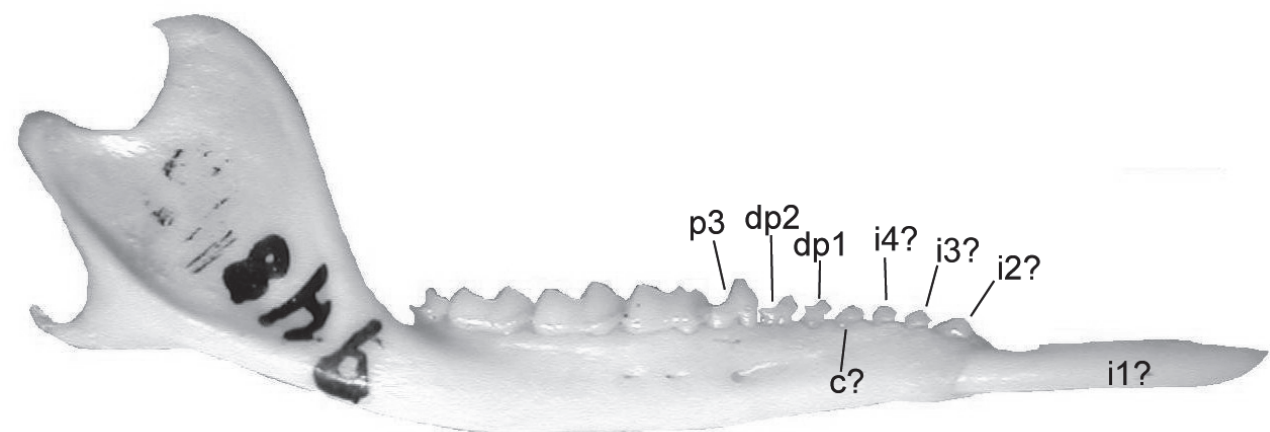

Fig. 4: Supernumerary tooth in the mandible of Rhyncholestes raphanurus (IEEUACH 948).

Diente supernumerario en la mandíbula de Rhyncholestes raphanurus (IEEUACH 948). 
Although little is known of the dental ontogeny and tooth eruption in D. gliroides, this pattern is consistent with the eruption pattern and teeth "relationships" observed in other marsupials. The peg-like single rooted $\mathrm{dP}^{1}$ represents a small (in relation to shape) deviation from the normal condition. First premolars are the smallest post canine teeth in marsupials [except for dP3 in Hyladelphys kalinowskii and Zygolestes paranensis (Voss et al. 2001, Goin 1997, respectively)], with reduced functionality due to their position behind $\mathrm{C}^{1}$. Supernumerary teeth were found in two different specimens of D. gliroides (IEEUACH 673 and IEEUACH 674) from the same locality and appear as peglike teeth at the end of the toothrow. Archer (1975) mentioned "...molars sometimes occur posterior to M4 in macropodids but rarely in other marsupials...except for a case of Dasyurus maculatus with left and right $\mathrm{M}^{5}$ and left $\mathrm{M}_{5}$ ". It is still debatable if these extra molars at the end of the toothrow represent an M5 or belong to a different tooth family (as proposed by Kirkpatrick 1969). Another alternative explanation could be that this extra tooth is formed by a splitting of the last molar's dental lamina during tooth development, thus giving place to M4 (which has two roots) and a peg-like M5 (while the dental lamina is still active). Unfortunately, answers to this can only be hypothesized until specimens with anomalies are sectioned. Only one specimen of D. gliroides exhibited two anomalies simultaneously (IEEUACH 687). In this case, the presence of fused $\mathrm{dP}^{1-2}$ augmented the space between $\mathrm{C}^{1}$ and $\mathrm{M}^{1}$, thus $\mathrm{C}^{1}$ appears slightly displaced backwards and $\mathrm{P}^{3}$ has moved mesially and presents anomalous crown morphology (see above).

In caenolestids the presence of supernumerary or missing teeth between the procumbent $\mathrm{I}_{1}$ and $\mathrm{dP}_{2}$ has been documented previously on a few occasions. Bublitz (1987) mentioned that $\mathrm{dP}^{1} \mathrm{~s}$ might be occasionally absent in Caenolestes (= Lestoros) inca, but he did not provide percentages or specimen numbers. Additional teeth in caenolestids have been documented only by Bensley (1903) and Osgood (1921), the former author illustrating a specimen with an additional tooth bilaterally and the latter a specimen bearing an additional tooth on the right dentary (FMNH 18603 as illustrated by Luckett \& Hong 2000). In both $C$. fuliginosus and $R$. raphanurus these anomalies were found in only one of the mandibles, and not on both sides. To establish the identity of these supernumerary or missing teeth is not possible (unless specimens showing anomalies are sectioned) due to the almost identical shape of $\mathrm{I}_{2-3}, \mathrm{C}_{1}$ and $\mathrm{dP}_{1}$ crowns (Fig. $2 \mathrm{~A}$ and $2 \mathrm{~B}$ ). In both species all these teeth are single rooted and the crown is very similar, with the exception of unworn $\mathrm{dP}_{1}$ 's in $R$. raphanurus, where a slightly developed talonid is present (e.g., IEEUACH 948 and IEEUACH 3578). Other anomalies observed in C. fuliginosus include an anomalous $\mathrm{dP}_{2}$ and a supernumerary tooth in an unusual position. Specimen BMNH 1954.295 has a left single rooted $\mathrm{dP}_{2}$ and buccolingually oriented crown, compressed mesiodistally. The reasons for abnormally shaped teeth like this one are not clear (Archer 1975), which could occur due to developing factors related to disturbance during tooth initiation. Because of its small size and position, $\mathrm{dP}_{2}$ has no negative direct consequence in occlusion. The other anomaly observed (BMNH 1954.297) is a supernumerary fully erupted tooth lingual to $\mathrm{I}^{2-}$ 3 , anterolabial to the incisive fenestra (Fig. 3). The shape of this tooth is unusual because it doesn't match any other tooth in the maxilla or mandible. Like the incisors it is single-rooted but the crown is pointed and laterally compressed, not chisel-like as the other incisors of the species. The occurrence of a supernumerary tooth in such a position is very rare because it contributes nothing to occlusion. Missing teeth in $R$. raphanurus were found in different positions: $\mathrm{I}^{4}, \mathrm{C}^{1}, \mathrm{P}_{3}$ (which seems to be broken) and $\mathrm{M}^{4}$. In IEEUACH 2250 (missing $\left.\mathrm{I}^{4}\right) \mathrm{C}^{1}$ is displaced mesially, increasing the distance (diastema) to $\mathrm{dP}^{1}$, which also appears slightly displaced mesially from $\mathrm{dP}^{2}$. This is also the case in specimen IEEUACH 2245 (missing $\mathrm{C}^{1}$ ) which shows a slight distal displacement of $\mathrm{I}^{4}$. No modifications in teeth position were found in specimens with missing $\mathrm{P}_{3}$ and $\mathrm{M}^{4}$ (IEEUACH 4000 and IEEUACH 3998, respectively). Morphological anomalies in $R$. raphanurus were found in the size and shape of $\mathbf{M}_{4}$. This tooth is small in all caenolestids, but preserves the trigonid-talonid structure with certain modifications, i.e., shortening in the antero-posterior axis, lowering of cusps and crests (personal 
observation). In two specimens (IEEUACH 949 and IEEUACH 4522) $\mathrm{M}_{4}$ is a single-rooted peg-like tooth, lacking a talonid.

Though the total number of specimens with anomalies is similar, there is a difference in occurrence and position of the anomalies in each species. Also, they appear to have very limited (or none at all) functional value in the three species analyzed. In D. gliroides, supernumerary teeth at the end of the tooth row do not occlude with lower counterparts, and thus are meaningless for chewing (personal observation). The fusion of the first two premolars could have some incidence depending on the type of food being consumed. Analysis of a captive specimen and its feeding and masticatory behavior with different food items has shown two main patterns: 1) the use of incisors when consuming moderately hard fruits (i.e., apples), scrapping the surface and swallowing the materials; and 2) the use of molars (and eventually premolars) to crush harder items (personal observation). Both patterns indicate a smaller usage of upper and lower premolars during food processing, mainly holding the food items that would eventually be passed backwards. The small and incisiform canines do not seem to add pressure in the antero-middle area of the mandible and maxilla, but in both cases in which dP1-2 were fused C1 was distally and P3 messially displaced, to fill the gap from unoccupied space. In both $C$. fuliginosus and $R$. raphanurus, there is no occlusion between the upper incisors, canine, and first two premolars in the maxillae with the teeth in the mandible. Only the procumbent lower incisors seem to complete the lingual side of upper counterparts acting as a shovel against a fixed unmovable surface (personal observation). Upper canines probably puncture the food items the animal is holding between its jaws (as described for the incisors by Kirsch \& Waller 1979) and the crushing still occurs in the P3-M3 section of the toothrow. In any case, a supernumerary or missing tooth between the procumbent lower incisors and $\mathrm{P}_{2-3}$ would have little influence in the animal's "holding-of-the-prey" capacity. The same happens with the modification of $\mathrm{M}_{4}$ 's crown pattern. On the other hand, a modification in the upper dentition (missing of $\mathrm{I}^{4}, \mathrm{C}^{1}$, or any upper premolar) would certainly influence that "holding" capacity. This is evident in the rearrangement of the remaining teeth (e.g., IEEUACH 2245) when $\mathrm{C}^{1}$ is missing, with $\mathrm{I}^{4}$ and $\mathrm{dP}^{1}$ closing the gap left by $\mathrm{C}^{1}$, as described above for D. gliroides (personal observation). The number of anomalies found in $R$. raphanurus is high, and has not been documented for any other species of mammal so far. In D. gliroides, the cases described here are in the proportional range of Australian dasyurids, but resemble the anomalies found in macropodi/yds.

Of the three species studied here, $D$. gliroides shows the smallest percentage of anomalies in specimens coming from $\sim 15$ localities (see Appendix 1). On the other hand, specimens of $C$. fuliginosus and $R$. raphanurus come from no more than seven localities throughout the species' range and have higher percentages of anomalies (Table 1). The distribution of $C$. fuliginosus and $R$. raphanurus, although different in extension and general environments, shows some similarities. C. fuliginosus inhabits highly insularized environments (i.e., the "páramos" and cloud forests at the highest portions of the northern Andes, at about $4,000 \mathrm{~m}$ of altitude) and $R$. raphanurus shows an isolated distribution inside patches of temperate rainforest (Patterson \& Gallardo 1987, M. Gallardo personal communication). Therefore, the distribution of these two species (in total area) is different from that of D. gliroides, most didelphids presented herein, and most Australian marsupials described by Archer (1975), all of which inhabit larger lessinsularized areas.

The temperate rainforests where both $D$. gliroides and $R$. raphanurus inhabit have experienced drastic modifications during the last million years, with fluctuations due to major glacial activity (Markgraf et al. 1996, Armesto et al. 1997) and anthropogenic disturbances (Veblen et al. 1996, Lara et al. 1997). Also, the habitat of $C$. fuliginosus has been subject to several disturbances from moderate glacial action to volcanic eruptions affecting different areas and at different scales throughout the geological history of the Andes (Parsons 1985). Therefore, a long history of isolation, perturbation and ongoing habitat reduction experienced during geological and recent times might be influencing the population dynamics of the three species 
described herein. Geographical isolation has been proposed as the cause for increased homozygosity of individuals by inbreeding, loss of allelic variation caused by random genetic drift and many other genetic effects that can affect populations, especially at small sizes. As shown above and in Appendix 1, specimens analyzed here come from a limited number of localities, especially $C$. fuliginosus and $R$. raphanurus. Conditions of inbreeding (or limited gene flow) between specimens of the sampled populations cannot be ruled out as the reason for some of the dental anomalies described herein. If this is the case then why doesn't $D$. gliroides present the high number of anomalies that occur in caenolestids? Possible explanations can be related to the evolutionary history of each species, their ecology, and the distribution of each species in their particular habitats. Recent work by Nilsson et al. (2004) shows different times of divergence (and hence different evolution times) for the clades that include Dromiciops on one side, and Caenolestes and Rhyncholestes on the other, with a difference of at least 10 million years between each lineage. The influence of this longer evolutionary history, together with different ecological requirements and environmental pressure might be responsible for the anomalies presented herein. Unfortunately, this can only be proposed as a mere hypothesis until more studies are made.

The phylogenetic significance (if any) of these anomalies should be taken carefully. Archer (1975) argued that most dental anomalies lack phylogenetic significance but mentions that others might be significant (not stating which). On the other hand, Hall (1928) interpreted the finding of supernumerary teeth in bears as atavisms. The information presented here does not support the idea of dental anomalies (e.g., missing teeth, cusp fusion) as cases of atavism, except maybe supernumerary teeth in caenolestids (but see below). Most of the anomalies discussed here lack any morphofunctional value and appear not related to any developmental pattern. In the cases described here for $C$. fuliginosus, $R$. raphanurus and $D$. gliroides, dental anomalies that do not interfere with the mastication process are not excluded (eliminated) from the population because there is a lack of pressure to do so. Therefore, stochastic events related to population dynamics (as genetic drift) might have an influence on which of the anomalies are commonly present and which are not. On the other hand, the presence of supernumerary teeth in the anterior region of the mandible of caenolestids (except the case of specimen BMNH 1954.297) can be discussed from a different perspective, either as an atavism or a vestige as described by Peterkova et al. (2006). If the ancestral mammalian lower incisor formula is accepted to be four (as proposed by Turnbull (1971) and Luckett (1993), to name just a couple) then the presence of an extra tooth between the procumbent incisors and the canine could be considered the "missing" or "lost" I ${ }^{4}$ (lost during the evolution of the group). Ziegler (1971) stated: "fossil records document that the evolutionary disappearance of a tooth is preceded by its progressive reduction in size and simplification in shape". If this is true, we should find a presence/ absence pattern and crown simplification in fossil caenolestids until the tooth is finally lost. The extension (elongation) of the anterior region of the mandible in recent caenolestids and the lack of direct pressure in the mastication process (see above) could derive in a relaxation in that area of the mandible, where more space would be available between teeth. This reduced pressure could have a direct effect on the dental lamina allowing for lost teeth to "re-appear". The presence of supernumerary teeth in extant caenolestids could then be considered atavisms and the dental formula of four upper/lower incisors. This hypothesis has major evolutionary consequences because it implies that the first pair of incisors in caenolestids (the procumbent ones) are the true first incisors $\left(\mathrm{I}^{1}\right)$ and not the second pair, and therefore homologous to the first upper ones. Unfortunately, until fresh sectioned specimens are available, the validity of a statement like this one can only be presented as hypothetical.

In sum, this contribution adds to a better knowledge of the dental morphology in a remarkable set of South American marsupials, one species (Dromiciops gliroides) because of its ties to the Australian radiation, and the other two because they represent a very old lineage exclusive (?) to South America. The work presented here leaves open lines for future investigation in relation to the species distribution/isolation and genetic drift 
processes. Also, further studies in these species should concentrate on the influence of teeth and their functional adaptations (in relation to feeding strategies and food consumption), and collecting specimens for sectioning techniques that could add valuable information on tooth formation and tooth homologies, especially in the case of caenolestids where the issue hasn't been solved yet.

\section{ACKNOWLEDGMENTS}

I thank curators who granted access to specimens under their care: D. Verzi and M. Merino (MLP), M. Gallardo (IEEUACH), R. Voss (AMNH), P. Jenkins (BMNH), R. Barquez and D. Flores (CML), B. Patterson (FMNH). N. Giannini kindly facilitated the specimens of $D$. gliroides under his temporary care and in loan from FMNH. F. Goin and M. Tejedor provided thoughtful comments that improved the original manuscript. My visit to the AMNH was sponsored by a Collection Study Grant. M. Simeon and E. Watkins provided financial support, especially during my visits to London and USA.

\section{LITERATURE CITED}

ALBUJA VL \& BD PATTERSON (1996) A new species of northern shrew-opossum (Paucituberculata: Caenolestidae) from the Cordillera del Cóndor, Ecuador. Journal of Mammalogy 77: 41-53.

ARCHER M (1975) Abnormal dental development and its significance in dasyurids and other marsupials. Memoirs of the Queensland Museum 17: 251-265.

ARMESTO JJ, P LEÓN-LOBOS \& MK ARROYO (1997) Los bosques templados del sur de Chile y Argentina: una isla biogeográfica. In: Armesto JJ, C Villagrán \& MK Arroyo (eds) Ecología de los bosques nativos de Chile: 23-28. Segunda edición. Editorial Universitaria, Santiago, Chile.

AZORIT C, J MUÑOZ-COBO \& M ANALLA (2002) Abnormal teeth in the Spanish red deer (Cervus elaphus hispanicus). Zeitschrift für Jagdwissenschaft 48: 252-260.

BENSLEY BA (1903) On the evolution of the Australian Marsupialia: with remarks on the relationships of the marsupials in general. Transactions of the Linnean Society of London 9: 83-217.

BENSLEY BA (1906) The homologies of the stylar cusps of the upper molars of the Didelphyidae. Studies of the University of Toronto, Biological Series 5: 1-13.

BIRNEY EC, RS SIKES, JA MONJEAU, N GUTHMANN \& CJ PHILLIPS (1996) Comments on Patagonian Marsupials from Argentina. In: Genoways HH \& RJ Baker (eds) Contributions in Mammalogy: a memorial volume honoring Dr. J. Knox Jones, Jr.:
149-154. Museum of Texas Tech University, Lubbock, Texas, USA.

BROWN B (2004) Atlas of New World marsupials. Fieldiana Zoology (New Series) 102: 1-308.

BUBLITZ J (1987) Untersuchungen zur Systematik der rezenten Caenolestidae Trouessart, 1898 unter Verwendung craniometrischer methoden. Bonner Zoologische Monographien 23: 1-96.

DOLGOV VA \& OL ROSSOLIMO (1964) Dental anomalies in Canis lupus Linnaeus, 1758. Acta Theriologica 8: 237-244.

GIANNINI, NP, F ABDALA \& DA FLORES (2004) Comparative postnatal ontogeny of the skull in Dromiciops gliroides (Marsupialia: Microbiotheriidae). American Museum Novitates 3460: 1-17.

GOIN FJ (1997) Sobre la edad y afinidades de Zygolestes paranensis Ameghino, 1898 (Marsupialia, Didelphidae, Marmosinae). Neotrópica 43: 15-19.

GOIN FJ (2003) Early Marsupial radiations in South America. In: Jones M, C Dickman \& M Archer (eds) Predators with pouches: the biology of carnivorous marsupials: 30-42. CSIRO Publishing, Sydney, Australia.

GONZÁLEZ EM (2000) Molares supernumeraries en Didelphis albiventris Lund, 1841 (Mammalia, Didelphimorphia, Didelphidae). Boletín de la Sociedad Zoológica de Uruguay (segunda época) 12: 41-43.

HALL ER (1928) Records of supernumerary teeth in bears. University of California Publications in Zoology 30: 243-250.

HERSHKOVITZ P (1999) Dromiciops gliroides Thomas, 1894, last of the Microbiotheria (Marsupialia), with a Review of the family Microbiotheriidae. Fieldiana Zoology (New Series) 93: 1-60.

HOOPER ET (1946) Extra teeth in a shrew. Journal of Mammalogy 27: 394.

KIRKPATRICK TH (1969) The dentition of the marsupial family Macropodidae with particular reference to tooth development in the grey kangaroo Macropus giganteus Shaw. PhD dissertation, Department of Zoology, University of Queensland, Queensland, Australia. $128 \mathrm{pp}$.

KIRSCH JAW \& PF WALLER (1979) Notes on the trapping and behavior of the Caenolestidae (Marsupialia). Journal of Mammalogy 60: 390-395.

KIRSCH JAW, AW DICKERMAN, OA REIG \& MS SPRINGER (1991) DNA hybridization evidence for the Australasian affinity of the American marsupial Dromiciops australis. Proceedings of the National Academy of Sciences 88: 10465-10469.

KIRSCH JAW, FJ LAPOINTE \& MS SPRINGER (1997) DNA-hybridization studies of Marsupials and their implications for Metatherian classification. Australian Journal of Zoology 45: 211-280.

LARA A, C DONOSO \& JC ARAVENA (1997) La conservación del bosque nativo de Chile: problemas y desafíos. In: Armesto JJ, C Villagrán \& MK Arroyo (eds) Ecología de los bosques nativos de Chile: 335-362. Segunda edición. Editorial Universitaria, Santiago, Chile.

LUCKETT PW (1993) An ontogenetic assessment of dental homologies in therian mammals. In: Szalay FS, MJ Novacek \& MC McKenna (eds) Mammal phylogeny: Mesozoic differentiation, multituberculates, monotremes, early therians and marsupials: 182-204. Springer-Verlag, New York, New York, USA.

LUCKETT PW \& PA WOOLEY (1996) Ontongeny and homology of the dentition in dasyurid marsupials: 
development in Sminthopsis virginae. Journal of Mammalian Evolution 3: 327-364.

LUCKETT PW \& N HONG (2000) Ontongenetic evidence for dental homologies and premolar replacement in fossil and extant caenolestids (Marsupialia). Journal of Mammalian Evolution 7: 109-127.

MARKGRAF V, E ROMERO \& C VILLAGRÁN (1996) History and paleoecology of South American Nothofagus forests. In: Veblen TT, RS Hill \& J Read (eds) The ecology and biogeography of Nothofagus forests: 354-386. Yale University Press, New Haven, Connecticut, USA.

MARTIN GM (2003) Nuevas localidades para marsupiales patagónicos (Marsupialia: Didelphimorphia y Microbiotheria) en el noroeste de la Provincia del Chubut. Mastozoología Neotropical (Argentina) 10: 148-153.

MARTIN GM (2005) Intraspecific variation in Lestodelphys halli (Marsupialia: Didelphimorphia). Journal of Mammalogy 86: 793-802.

NILSSON MA, U ARNASON, PBS SPENCER \& A JANKE (2004) Marsupial relationships and a timeline for marsupial radiation in South Gondwana. Gene 340: 189-196.

NOWAK RM (1999) Walker's mammals of the world. Sixth edition. John Hopkins University Press, Baltimore, Maryland, USA. 1,927 pp.

NUNES E, I GOMES DE MORAES, P MÁRCIO DE OLIVEIRA NOVAES \& SM GALVÃO DE SOUSA (2002) Bilateral fusion of mandibular second molars with supernumerary teeth: case report. Brazilian Dental Journal 13: 137-141.

OSGOOD WH (1921) A monographic study of the American marsupial, Caenolestes. Field Museum of Natural History Zoology Series 14: 1-162.

OSGOOD WH (1924) Review of living Caenolestids with description of a new genus from Chile. Field Museum of Natural History Zoological Series (USA) 14: 165-172.

PARSONS JJ (1985) El medio ambiente de los Andes del norte. In: Johnson DV (ed) Informe sobre los conocimientos actuales de los ecosistemas andinos: Los Andes Septentrionales: cambios ambientales y culturales: 15-34. MAB, UNESCO/PNUMA. ROSTLAC, Montevideo, Uruguay.

PATTERSON BD \& MH GALLARDO (1987) Rhyncholestes raphanurus. Mammalian Species 286: 1-5.

PATTERSON BD, PL MESERVE \& BK LANG (1989) Distribution and abundance of small mammals along an elevational transect in temperate rain forests of Chile. Journal of Mammalogy 70: 67-78.

PAVLINOV YI (1975) Tooth anomalies in some Canidae. Acta Theriologica 20: 507-519.

PETERKOVA R, H LESOT \& M PETERKA (2006)
Phylogenetic memory of developing mammalian dentition. Journal of Experimental Zoology 306B: $1-17$.

REIG OA (1955) Noticia preliminar sobre la presencia de microbiotherinos en la fauna Sudamericana. Investigaciones Zoológicas Chilenas 2: 121-129.

SPRINGER MS, M WESTERMAN, JR KAVANAGH, A BURK, MO WOODBURNE, DJ KAO \& C KRAJEWSKI (1998) The origin of the Australasian marsupial fauna and the phylogenetic affinities of the enigmatic monito del monte and marsupial mole. Proceedings of the Royal Society of London, Biological Sciences 265: 2381-2386.

SZALAY FS (1982) A new appraisal of marsupial phylogeny and clasification. In: Archer M (ed) Carnivorous marsupials: 621-640. Royal Zoological Society of New South Wales, Sydney, Australia.

SZALAY FS (1994) Evolutionary history of the marsupials and an analysis of osteological characters. Cambridge University Press, Cambrigde, United Kingdom. 495 pp.

TURNBULL WD (1971) The trinity therians: their bearing on evolution in marsupials and other therians. In Dahlberg AA (ed) Dental morphology and evolution: 151-179. The University of Chicago Press, Chicago, Illinois, USA.

VAN NIEVELT AFH \& KK SMITH (2005) To replace or not to replace: the significance of reduced functional tooth replacement in marsupial and placental mammals. Paleobiology 31: 324-346.

VEBLEN TT, C DONOSO, T KITZBERGER \& AJ REBERTUS (1996) Ecology of southern Chilean and Argentinean Nothofagus forests. In: Veblen TT, RS Hill \& J Read (eds) The Ecology and biogeography of Nothofagus forests: 293-353. Yale University Press, New Haven, Connecticut, USA.

VIDIGAL VCS \& JL PATTON (1996) Determination of dental age classes in Amazonian woolly mouse opossums, with notes on intergeneric-variation. Berkeley McNair Journal, University of California, Berkeley, California, USA, Winter 1996, 4: 82-93.

VOSS RS, DP LUNDE \& NB SIMMONS (2001) The mammals of Paracou, French Guiana: a Neotropical lowland rainforest fauna: part. 2, nonvolant species. Bulletin of the American Museum of Natural History (USA) 263: 1-236

WESTERMAN M \& D EDWARDS (1991) The relationship of Dromiciops australis to other marsupials-data from DNA/DNA hybridization studies. Australian Journal of Zoology 39: 123-130.

ZIEGLER AC (1971) A theory of the evolution of dental formulas and replacement patterns. Quarterly Review of Biology 46: 226-249. 


\section{APPENDIX 1}

Specimens of Dromiciops gliroides, Caenolestes fuliginosus and Rhyncholestes raphanurus examined in this study with localities and museum specimen numbers. Museum and collection acronyms are: AMNHAmerican Museum of Natural History, New York, USA; BMNH- Natural History Museum, London, UK; CML- Colección "Miguel Lillo", Universidad Nacional de Tucumán, Tucumán, Argentina; FMNH- Field Museum of Natural History, Chicago, USA; IEEUACH- Instituto de Ecología y Evolución Universidad Austral de Chile, Valdivia, Chile; MACN- Museo Argentino de Ciencias Naturales "Bernardino Rivadavia,' Buenos Aires, Argentina; MLPMuseo de La Plata, La Plata, Argentina

Especímenes de Dromiciops gliroides, Caenolestes fuliginosus y Rhyncholestes raphanurus examinados en este estudio con localidades y número de ejemplar. Los acrónimos de cada museo y colección son los siguientes: AMNH-American Museum of Natural History, New York, USA; BMNHNatural History Museum, London, UK; CMLColección "Miguel Lillo", Universidad Nacional de Tucumán, Tucumán, Argentina; FMNH- Field Museum of Natural History, Chicago, USA; IEEUACH- Instituto de Ecología y Evolución Universidad Austral de Chile, Valdivia, Chile; MACN- Museo Argentino de Ciencias Naturales "Bernardino Rivadavia,' Buenos Aires, Argentina; MLPMuseo de La Plata, La Plata, Argentina

Dromiciops gliroides. - Argentina: Neuquén Province; Cerro Chapelco, $40^{\circ} 14^{\prime} \mathrm{S}, 71^{\circ} 16^{\prime} \mathrm{W}$ (MLP 8.IV.02.11); Río Negro Province; Parque Municipal Llao-Llao $41^{\circ} 03^{\prime} \mathrm{S}, 71^{\circ} 32^{\prime} \mathrm{W}$ (CML 1869); Isla Victoria, 40 ${ }^{\circ} 56^{\prime} \mathrm{S}, 71^{\circ} 33^{\prime} \mathrm{W}$ (MACN 48.26, MLP 6.XI.41.4); MACN 13038; MACN 19142. Chile: BMNH 1892.5.9.3; Valdivia Province; Comuna La Unión, Catamutún, $40^{\circ} 07^{\prime} \mathrm{S}, 73^{\circ} 07^{\prime} \mathrm{W}$ (IEEUACH 691-IEEUACH 693, IEEUACH 682); Comuna de Valdivia, $39^{\circ} 50^{\prime} \mathrm{S}, 72^{\circ} 45^{\prime} \mathrm{W}$ (IEEUACH 671-IEEUACH 681); Fundo San Martín, $39^{\circ} 38^{\prime} \mathrm{S}, 73^{\circ} 07^{\prime} \mathrm{W}$ (IEEUACH 683-IEEUACH 690, IEEUACH 1059, IEEUACH 1737 , IEEUACH 3130, IEEUACH 4324-IEEUACH 4325); Fundo Santa Rosa, $39^{\circ} 50^{\prime} \mathrm{S}, 72^{\circ} 45^{\prime} \mathrm{W}$ (IEEUACH 1731-IEEUACH 1734, IEEUACH 3131); Rupanco, Piedras Negras, $40^{\circ} 52^{\prime} \mathrm{S}$,
72 ${ }^{\circ} 17^{\prime}$ W (IEEUACH 1056-IEEUACH 1058, IEEUACH 1735); Arauco Province; Comuna Curanilahue, $37^{\circ} 26^{\prime} \mathrm{S}, 73^{\circ} 21^{\prime} \mathrm{W}$ (IEEUACH 1053-IEEUACH 1054); Osorno Province; La Picada, Puerto Octay, $41^{\circ} 06^{\prime} \mathrm{S}, 72^{\circ} 30^{\prime} \mathrm{W}$ (IEEUACH 2144-IEEUACH 2157, IEEUACH 2159, IEEUACH 2160, IEEUACH 2163IEEUACH 2166, FMNH 127448, FMNH 127450-FMNH 127451, FMNH 127454-FMNH 127455, FMNH 127457-FMNH 127464, FMNH 129806-FMNH 129810, FMNH 134556); Palena Province; Contao, $19.7 \mathrm{~km}$ north of Rio Negro \& $26.7 \mathrm{~km}$ south of Contao, $41^{\circ} 58^{\prime}$ S, $72^{\circ} 38^{\prime}$ W (FMNH 129812-FMNH 129813); Río Negro, 12.4 km west-northwest, 41 ${ }^{\circ} 58^{\prime} \mathrm{S}, 72^{\circ} 34^{\prime} \mathrm{W}$ (FMNH 134624); Chiloé Province; Cucao, $42^{\circ} 38^{\prime} \mathrm{S}, 74^{\circ} 07^{\prime} \mathrm{W}$ (IEEUACH 6996, IEEUACH 6999); Palomar, Fundo El Venado, $42^{\circ} 03^{\prime} \mathrm{S}, 73^{\circ} 58^{\prime} \mathrm{W}$ (IEEUACH 6998-IEEUACH 7000).

Caenolestes fuliginosus. - Ecuador: Chupitán, Pichincha, geographical coordinates not recorded (BMNH 1954.283); Gualea, Pichincha, north east side, $00^{\circ} 07^{\prime}$ 'S, $78^{\circ} 50^{\prime} \mathrm{W}$ (BMNH 1934.9.10.275); M[oun]t Pichincha, geographical coordinates not recorded $(\mathrm{BMNH}$ 1954.300-BMNH 1954.301, BMNH 1954.295BNMH 1954.297, BMNH 1954.299); N[ea]r Mindo, 0002' S, 7848' W (BMNH 1954.282); Pichincha M[oun]t., northeast side, geographical coordinates not recorded (BMNH 1978.2848, BMNH 1966.2826, BMNH 1924.4.18.11-BMNH 1924.4.18.17, BMNH 1934.9.10.267-BMNH 1934.9.10.274, BMNH 1934.9.10.276-BMNH 1934.9.10.278); Pichincha Volcano, $00^{\circ} 01^{\prime} \mathrm{S}, 79^{\circ} 49^{\prime} \mathrm{W}$ (BMNH 1954.288-BMNH 1954.289, BMNH 1954.291-BMNH 1954.293); Pichincha, above Quito, geographical coordinates not recorded (BMNH 1971.924); Pichincha, n[ea]r Quito, geographical coordinates not recorded (BMNH 1954.294, BMNH 1954.298); Pichincha, Pichan, 00¹0' S, 78³6' W (BMNH 1954.284, BMNH 1954.286-BMNH 1954.287).

Rhyncholestes raphanurus. - Argentina: Río Negro Province; Parque Nacional Nahuel Huapi, Puerto Blest, $41^{\circ} 02.15^{\prime}$ S, $71^{\circ} 48.54^{\prime} \mathrm{W}$ (MACN 20625). Chile: Osorno Province; Comuna Entre Lagos, Puyehue, 71 ${ }^{\circ} 50^{\prime} \mathrm{S}$, 40³6' W (IEEUACH 3998-IEEUACH 4000); Comuna Puerto Octay, La Picada, $41^{\circ} 06^{\prime} \mathrm{S}$, 72³0' W (BMNH 1975.1723 [4 km east], IEEUACH 947-IEEUACH 952, IEEUACH 
2241-IEEUACH 2247, IEEUACH 2249IEEUACH 2250, IEEUACH 2252, IEEUACH 3576, IEEUACH 3578); Vicente Perez Rosales National Park, (IEEUACH 4522); Chiloé
Province; Palomar, Fundo El Venado, $42^{\circ} 03^{\prime} \mathrm{S}$, 735' W (IEEUACH 1831, IEEUACH 1835);

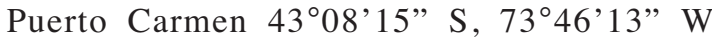
(IEEUACH 1840). 